\title{
XXXIX. On the true geological position of the macigno formation in Italy and in the South of Europe
}

\section{Prof. Leopold Pilla}

To cite this article: Prof. Leopold Pilla (1845) XXXIX. On the true geological position of the macigno formation in Italy and in the South of Europe , Philosophical Magazine Series 3, 26:173, 273-278, DOI: $10.1080 / 14786444508645129$

To link to this article: http://dx.doi.org/10.1080/14786444508645129

冓 Published online: 30 Apr 2009.

Submit your article to this journal $[\pi$

Џll Article views: 2

Q View related articles $\sqsubset$ 
LONDON, EDINBURGH AND DUBLIN

PHILOSOPHICAL MAGAZINE

A N I)

JOURNAL OF SCIENCE.

[THIRD SERIES.]

$A P R I L 1845$.

XXXIX. On the True Geological Position of the Macigno Formation in Italy and in the South of Europe. By Prof. Leopold Pilla*.

A MONG the formations which are the most extended in Italy, the macigno occupies a remarkable place. A great portion of the heights of Tuscany and of Liguria is composed of this formation, which extends also, on one side into the maritime Alps and those of Lombardy; on the other, into the kingdom of Naples and as far as Sicily. On leaving Italy we meet it with the same characters in the Pyrenees, on the northern sides of the Alps, in Greece, in Turkey, and, in general, in all the southern portion of Europe. It appears to mark the principal line of division between the geological zone of the north and the south of Europe,-a line which, as regards the formations under consideration, does not appear to extend on the west beyond Provence and the province of Nice; on the east, the Carpathian Mountains. At the commencement of this century, and during the prevalence of the Wernerian theories, false ideas were entertained respecting the age of this formation, which was generally considered as belonging to the graywacke $\dagger$. But it was soon seen that it occupied in Italy a place between the Jurassic and the tertiary formations; and from that time the necessity was seen of carrying its age up to the chalk. 'This idea has been more and more confirmed, and at present it is adopted by all geologists, only that very little attention has been paid to fixing with precision the stage which the macigno occupies in the cretaceous group. But a particular study of this deposit, a more thorough examination of its geological relations, of the fossils which characterize it, and of many accidental circumstances

* From the Comptes Rendus de l'Acad. des Sciences, January 1845.

+ Brocchi, Conchiologia Fossile Subapennina.

Phil. Mrg. S. 3. Vol. 26. No. 173. April 1845. 
which accompany it, have caused doubts in my mind respecting the position which is generally assigned to it; I would even say, have convinced me that this formation is wholly di. stinct, and independent of the chalk. I have been led to this conclusion by the exposition and the analysis of the facts which will form the object of the memoir which I have the honour to submit to the Academy. I shall divide this memoir into three parts :-1st, the distinction of the chalk formation in Italy; 2nd, a comparison of the chalk formation of Italy with that of France and of England; 3rd, the independence of the macigno and its geological position.

\section{Distinction of the Chalk Formation in Italy.}

It is generally agreed to divide the chalk formation in Italy into two portions, the upper and lower. The first is composed of the macigno; the second of a linestone, which, being characterized principally by species of Rudista, may be oalled hippuritic.

The macigno formation is so well known, that I shall not dwell long in describing its characters. I shall only observe that it is composed of two kinds of rocks, of a calcareous marl alternating with schists, which is commonly named Alberese in Tuscany, and of the macigno properly so called. The relative geological position of these two rocks is not absolutely constant. M. Pareto assures us that in Liguria the alberese is always superposed on the macigno; I have apparently seen the same thing in Tuscany, but in some localities the two rocks alternate and are mingled together. The fossils which most generally characterize the macigno are Fucoids, the most abundant species of which are $F$. intricatus, furcatus, Targioni. With regard to animal species, they are of extreme rarity: Nummulites have been found at Mosciano, near Florence, and I have met with some at Alberona, in the Pouille. I must mention another very important fossil found by the celebrated Micheli in the pietra forte of Florence; it is a fragment of a chambered shell, which, by the contour of the spiral, seems to belong to a Hamites, or perhaps to an Ancyloceras. This valuable fossil has been preserved in the collection of Targioni at Florence, where it was observed by Brocchi*, by Nesti, and by Savi; the last also took a cast of it in plaster, which is now in the museum of the University of Pisa. It is truly to be regretted that the specimen I speak of has been lost in the changes which the above-mentioned collection has undergone. At the congress held at Milan, my friends MM. Pentland and Pareto assured me that they had found two

* Conchiologia Fossile Subapennina, tomo i. p. 17. 
Ammonites; one in the pietra forte, with which the city of Florence is paved, the other in the macigno of the environs of Genoa. These discoveries are important, on account of the rarity of animal remains in the formation which we are now considering. Carbonaceous deposits are also found in the macigno, such as the stipites of Pupiglio in the Pistojais, of the valley of the Taro, in Lunigiana, \&c.*

I will now say a few words of the extent of this formation in Italy. In the map of Sicily by M. Hoffmann, it is represented by the grès apennin à fucoüdes, by the conglomerate subordinate to the latter, and by the argillaceous schists. In the country of Naples, on this side of the lighthouse, the formation of the macigno is very rare; $I$ have only observed it in the mountains of Bovino in the Capitanate, with Fucoids quite similar to those of the Tuscan macigno. I could not point out the spots in the Papal states where this formation is found, with the exception of the Apennines of Bologna, where it is continuous with that of Florence. The macigno of Tuscany, of the Modenese and of Liguria is so classic, that I shall content myself with merely naming it here. It is also found, and very distinct, at the foot of the Alps of Lombardy, especially in the environs of Gavirate, where it has been examined by the Geological Section of the meeting held at Milan. This locality is very remarkable, not only for the great number of Fucoids perfectly similar to those of the macigno of Florence which it contains, but also for other species which remain to be determined by some able algologist.

\section{Comparison of the Chalk Formation of Italy roith that of} France and of England.

In this part the author attempts to establish the fact, that three rleposits of nummulites are distinguishable in Italy :-1 st, the tertiary ones of the Vicentin, if, however, they shall continue to retain the place which they have hitherto occupied; 2 nd, the nummulites of the macigno; $3 \mathrm{rd}$, those of the hippuritic formation. We may reason, à priori, that their species must be different in these three positions; but it is desirable that, for the interests of science, some able palæontologist should undertake the task of classing them, in order that they may serve as marks for the distinction of the deposits which contain them $\dagger$.

He ends by concluding, that the facts which he has related tend to establish, -

* An account of one of these deposits of lignite in Lunigiana, by Prof. Mojon, will be found in Phil. Mag., First Series, vol. xvi. p. 324. Enir.

+ 'This work is promiscd us by $M$. Leymerie, who, by its execution, will without doubt render a great service to the geology of the south of Europe. - Note by M. Pilla.) 
1st. That the northern chalk is connected with the nummulitico-hippuritic limestone of the south of Europe, but never with the macigno, which is above this.

2nd. That the nummulitico-hippuritic limestone of Italy represents all the northern cretaceous limestone; in the greatest part the upper and lower greensand, and only in certain localities the white chalk.

\section{Independence of the Macigno Formation.}

If we admit that the nummulitico-hippuritic limestone of the Mediterranean is the representative of the whole of the chalk of the north of Europe, and that the macigno is superposed on this limestone, we must admit also that this formation constitutes a peculiar deposit and one wholly distinct from the chalk. This distinction is based on all the characters which establish the independence of a formation,- on the mineralogical characters, on the superposition, and on the fossils, as we shall presently remark.

The macigno of 'Tuscany and of Liguria, which is the most classic, has no mineralogical analogy with the chalk of the north-west of Europe; the rocks which compose it have quite peculiar characters. 'Io this difference we must add another very remarkable circumstance; the flint, which appears to be a substance almost inseparable from the upper northern chalk, is entirely wanting in the Italian macigno; and, although this circumstance may be considered in general as of little value, it is of great weight in this special case. 'There have likewise not been found any of those green particles which are frequently met with in the cretaceous greensand of the nortb, whence it takes its name.

With regard to the superposition, we have seen, first, that the macigno must be considered as above the white chalk. In the second place, we have observed that the different beds of the nummulitico-hippuritic limestone, which are parallel to the beds of the northern chalk, are connected together by insensible gradations, which proves that they have been deposited in the same sea, and under the same circumstances; whilst the macigno is always separated from these deposits by a wellmarked line and by different topographical circumstances, and never mixes with them, which is an evident sign that it has been deposited in a different sea, and under different circumstances. Lastly, if one of the principal characters of the independence of a formation is its superposition on rocks of various ages, this is verified in the macigno more than in any other formation, because it is seen superposed at one time on the nummulitico-hippuritic limestone (Liguria), at another on the Jura 
limestone (Tuscany); lastly, at another locality on crystalline rocks (Isle of Elba). And it is a truly remarkable thing, that in Tuscany, where this formation is very greatly developed, it is never found associated with the nummulitico-hippuritic limestone,-so independent is it of this latter.

In the last place come the fossils to confirm the distinction established. There has never been found, either in the macigno of Tuscany, or in that of any other locality, that I know, any fossil belonging to the chalk formation of the north-west of Europe. It is a well-known fact, that the principal organic remains which characterize this formation are the Fucoids. Now these are wholly wanting in the northern chalk formation; and, a fuct which deserves to be remarked, they are also wanting in the southern nummulitico-hippuritic limestone. On the contrary, the Rudista, which are very abundant in this last deposit, may be considered as entirely foreign to the first, not a single individual having hitherto been found in it. The saine must be said of the Actionella, which habitually accompany the Rudiste. M. d'Orbigny has shown that this latter family (comprising in it the Cranice) occur in all the strata of the chalk formation of Europe. If then it has no species which represents it in the macigno, we must conclude that this deposit does not belong to the cretaceous system. Perhaps we might cite the Nummulites, which are common to the macigno and to the limestone which is below it, and the Ammonites, which have been taken from the macigno of ' $\Gamma$ uscany and Liguria; but, without regarding the extreme rarity of these fossils in the macigno, can it be affirmed that the species are the same as those which we find in the nummulitic limestone? No one can assert this*.

We may then conclude,-

1st. That the macigno has different mineralogical characters from those of the chalk.

2nd. 'That it is superposed on the nummulitico-hippuritic limestone, the upper part of which is connected with the white chalk of the north of Europe.

3rd. That it does not contain any fossil of the northern chalk, but that it contains Fucoids, absent in the latter as well as in the southern nummulitico-hippuritic limestone.

All the facts which I have here detailed appear to me to

* The Nummulites of the cretaceous limestone of Italy are ordinarily of a large size, and resemble the Nummulites of Peyrehorade in the Pyrenees, which are figured in Lyell's Elements of Geology (cretaceous group). Of this nature are the species which I have found in the Gargano, and those which M. Pareto cites in the limestone of Mortola, in Liguria. On the contrary, the Nummulites which have hitherto been found in the macigno are much smaller.-(Note by M. Pilla.) 
prove evidently that the macigno formation is wholly independent of the chalk formation, and that it may be separated from it by characters of a greater value than those which have served to determine the distinction of the Devonian and Silurian carboniferous formations. We must consider it as the last secondary deposil, occupying a place between the chalk and the tertiary formations. In the period in which it was deposited a change had taken place in the nature of the sediments in relation to those of the anterior (cretaceous) period; the one had been entirely calcareous, the others in great part arenaceous. In the period of the macigno, the family of the Rudiste had ceased to people the seas of the south of Europe, and with it had disappeared also the Nerinece, and almost the whole of the Actionelle; only some few species of Nummulites and Ammonites had continued their languishing existence, to become extinct at the end of these deposits. These considerations authorize me then to distinguish the macigno as a formation of a particular age, and to assign to it a special name, on account of the great part it acts in the sediments of southern Europe. I propose to name it the Etrurian System, for the reason that it has been recognised for the first time in a classical manner in the soil of Tuscany. I conclude these observations on the macigno, and on the chalk formation of Italy, by confronting their divisions in a Table with those of the northern chalk.

\begin{tabular}{|l|l|l|}
\hline Etrurian formation $\ldots$ & Northern zone. & \multicolumn{1}{|c|}{ Southern zone. } \\
\hline Wanting ............ & Upper chalk formation & White chalk $\ldots \ldots . .\left\{\begin{array}{l}\text { Alberese. } \\
\text { Macigno. } \\
\text { Indistinct. Limestone } \\
\text { with Ostrea vesicularis, } \\
\text { Catillus, Belemnites mu- } \\
\text { cronatus, \&c. } \\
\text { Llauconie and nummulitic } \\
\text { limestone. } \\
\text { tion }\end{array}\right.$ \\
$\begin{array}{l}\text { Wanting, or indistinct. } \\
\text { Neocomian formation. }\end{array}$ \\
\hline
\end{tabular}

XL. On the Changes produced in Metallic Wires rohich have served a long time as Electric Conductors. By M. PeLtien, in a Letter to M. Arago*,

THE important and beautiful experiment which you are about to make on the conductibility of wires, in the establishment of an electric telegraph, induces me to communicate to you two facts which are incidentally connected with this subject. About twelve years ago, being desirous of tracing

* From the Comptes Rendus, \&c., January 1845 . 